\title{
Consumer satisfaction and word-of-mouth in Electronic Commerce: a possible segmentation method
}

\author{
Completed Research Paper
}

\author{
Ildikó Kemény \\ Corvinus University of Budapest \\ ildiko.kemeny@uni-corvinus.hu \\ Ákos Nagy \\ University of Pécs, Faculty of Business and \\ Economics \\ nagya@ktk.pte.hu
}

\author{
Judit Simon \\ Corvinus University of Budapest \\ judit.simon@uni-corvinus.hu \\ Krisztián Szű́cs \\ University of Pécs, Faculty of Business and \\ Economics \\ szucsk@ktk.pte.hu
}

\begin{abstract}
Over the last 10 years the $\mathrm{B} 2 \mathrm{C}$ online market and its characteristics - for example the perceived electronic service quality (e-SQ) - has become a relevant research area, not only in the Western countries but also in smaller, less-developed countries. Therefore the first aim of this paper is to provide a description of an analysis into how the dimensions of perceived eSQ relate to satisfaction and WOM intention in Hungary. Secondly, using the results of a PLS-SEM model we show how consumers may be segmented based on their perceptions of quality. According to our research only the dimension of efficiency and responsiveness have a significant positive effect on satisfaction, and the perception of the quality of fulfilment's also significantly influences word-of-mouth intention. Using the relevant latent variable scores a segmentation method was developed in which four significantly different segments were identified.
\end{abstract}

Keywords: e-service quality perception, segmentation, e-commerce, word-of-mouth

\section{Introduction}

Over the last 10 years the business-to-consumer online market has grown at a fast pace, not only in the Western countries but also in smaller, less-developed countries, such as Hungary. In 2011, the combined revenue of Hungarian web-shops was 115 billion HUF (54 million EUR), which represents a more than 20 billion HUF (6.8 million EUR) increase over 2010 revenues (Enet, 2011, 2012). The number of online consumers is also growing: $25 \%$ of Hungarians bought something online in 2012. The most popular goods purchased online are: books and magazines (44\% of online-buyers); clothes, sporting goods (40\%); and travel and holiday accommodation (36\%) (Eurostat, 2013). These facts contribute to the reason why ecommerce has become a relevant and important business research field in Hungary.

E-commerce offers several advantages relative to the brick-and-mortar environment. Such advantages include personalization, an increasing range of products and information, and interactivity. Some risks have also appeared along with the benefits. Opportunities for fraud and abuse are higher in an impersonal and automated environment. Consequently, safety and quality of service has a more important role than in an offline environment. Therefore it is 
important for companies to have a well-founded strategy that they can base their electronic service quality on.

This paper is written with two main aims. The first aim is to provide a description of an analysis into how the dimensions of perceived quality relate to satisfaction and word-of-mouth intention in a Hungarian online bookshop. Secondly, using the results of a PLS-SEM model we show how consumers may be segmented the based on their perceptions of quality. This method is important because the dimensions of perceived quality are usually measured using multi-item scales. However, with this method it is not separate items or the sum or average scores that are used, but latent variable scores. Based on the results of such segmentation processes managers could build up a strategy which helps them to improve the level of satisfaction and word-ofmouth intention of consumers. In our research the E-S-Qual and its second scale, E-RecS-Qual were used under the Hungarian circumstances.

\section{Underlying theoretical frameworks}

Online purchasing results in a different customer experience than offline purchasing: buyers are searching and communicating in a virtual world and human-machine interactions are replacing interpersonal interactions (Bressoles, Durrieu, \& Giraud, 2007). The number of selfservice interactions is higher (Meuter, Ostrom, Roundtree, \& Bitner, 2000). The Internet as a marketing and sales channel has a lot of advantages (interactivity, personalization, the community, huge product and information supply) that necessitate the introduction of new research concepts as well (Wolfinbarger \& Gilly, 2003). In this impersonal, automated environment the risk to the consumer is also higher, hence privacy plays a more important role (Bressoles, Durrieu, \& Giraud, 2007).

Based on these facts, e-service quality needs a new approach, but the dimensions of eservice quality are differently defined in marketing literature. To better understand the concept of e-service quality perception, Parasuraman, Zeithalm and Malhotra (2005) suggest that the differences between traditional services quality and e-service quality should be analysed.

Electronic-service quality is a complex concept that includes aspects of the buying process that precede and follow the actual purchase. It covers not only the information-seeking processes and the use of a website, but also purchase, fulfillment, goods delivery, and occasional return and compensation. A broadly-accepted definition of perceived e-service quality is: "The extent to which a Web site facilitates efficient and effective shopping, purchasing, and delivery." (Parasuraman, Zeithaml, \& Malhotra, 2005, pp. 5).

Perceived quality could be described - also in the online environment - as the difference between consumer perceptions and the company's performance (Parasuraman, Zeithaml, \& Malhotra, 2005). During the evaluation process the consumers' expectations play a relevant role, which is influenced by earlier experiences, situational effects, company communication and word-of-mouth (Hill, 1986; Hofmeister-Tóth, Simon, \& Sajtos, 2003; Kenesei \& Kolos, 2007). Perceptions of quality have a significant relationship to satisfaction, and its consequences. According to the disconfirmation paradigm, if perceived quality is lower than the expected, consumers may leave a company, or complain (Folkes, 1984; Szymanski \& Henard, 2001). If this relationship is reversed - i.e. perceived quality is equal to or higher than expected - then consumers will be satisfied, which will lead to positive word-of-mouth, or repurchasing intentions (Oliver \& Rust, 1997, Szymanski \& Henard, 2001, Chang et al., 2009), and long-term loyalty (Cronin \& Taylor, 1992).

To measure e-service quality several scales have already been established in the literature (Loiacono, Watson, \& Goodhue, 2007; Barnes \& Vidgen 2001; Yoo \& Donthu 2001; Francis \& White 2002, Wolfinbarger \& Gilly, 2003; Parasuraman, Zeithaml, \& Malhotra, 2005; 
Francis, 2009), but according to the critics most of the concepts do not have content validity because they do not fit the definition of e-service quality - because they do not cover all stages of the buying process (information seeking, transaction, delivery, consumer service) (Wolfinbarger \& Gilly, 2003; Parasuraman, Zeithaml \& Malhotra, 2005). Based on our literature summary, we can establish that WebQual TM (Loiacono, Watson, \& Goodhue, 2007), SITEQUAL (Yoo \& Donthu, 2001), Web Qual 4.0 (Barnes \& Vidgen, 2001) do not have content validity because the dimensions of these scales do not deal with post-purchasing interactions such as delivery and consumer service. They concentrate only on quality of the site and the transaction (Kemény, Simon, \& Ugray, 2013).

The other fact that makes the construction of web-shops quality more complex is that some of its dimensions belong to the online environment, such as information-seeking and transactions, and some parts, for example with physical goods, belong to the offline environment. Analysing the nature of the relevant dimensions it also could be concluded that some dimensions of e-service quality are technology-based (for example system availability), while others are human-based (for example, consumer service, the reliability of the information), and sometimes the delivery service is provided by an external company.

In this study we used the broadly-accepted E-S-Qual scale, and a second scale, E-RecSQual, which was established in 2005 by Parasuraman, Zeithalm and Malhotra. The E-S-Qual scale includes 4 dimensions, and the E-RecS-Qual includes 3. The main scale has a second scale because the results of the research showed that e-service has some dimensions connected to compensation and responsiveness, but these items are not relevant to all customers. This scale is relevant only to customers who had a problem with the site or purchasing process.

The earlier scale included 11 dimensions (reliability, responsiveness, access, flexibility, ease of navigation, efficiency, assurance/trust, security/privacy, price knowledge, site aesthetics, and customization/personalization) that were reduced to $4+3$. The four dimensions of E-S-Qual (Parasuraman, Zeithaml, \& Malhotra, 2005) are the following:

1. Efficiency: How easy and fast is the access and usage of the site? - Internal, technologybased characteristic (measured with 8 items)

2. System availability: The correct technical functioning of the website. - Internal, technology-based characteristic (measured with 4 items)

3. Fulfilment: Are the promises fulfilled? - External, human-based characteristic (measured with 7 items)

4. Privacy: Does the site protect customer information? - Internal, technology-based characteristic (measured with 3 items)

The second scale, E-RecS-Qual's dimensions are:

1. Responsiveness: Does the site handle problems in a correct way? - Internal, humanbased characteristic (measured with 5 items)

2. Compensation: How does the site/vendor compensate if a customer has a problem? Internal, human-based characteristic (measured with 3 items)

3. Contact: Does the site have online or phone representatives? - Internal, human-based characteristic (measured with 3 items)

The second scale (E-RecS-Qual) includes the internal, human-based components of the site such as consumer service and complaint handling, which are especially important to the webshops because there is no personal interaction with the seller and the buyer cannot touch the purchased physical goods.

Many authors agree that perceived electronic service quality is an antecedent of satisfaction (Wolfinbarger \& Gilly 2003, Parasuraman, Zeithaml, \& Malhotra, 2005, Bressoles, Durrieu, \& Giraud, 2007), and it also has a direct effect on the consequences of satisfaction (Godwin, Bagchi, \& Kirs, 2010; Carlson \& O'Cass 2011). Following this tradition we also analyze the relationship of these two constructs in e-commerce. According to Anderson and Srinivasan 
(2003, 125. pp.), e-satisfaction is "contentment of the customer with respect to his or her prior purchasing experience with a given electronic commerce firm".

Most of the formerly mentioned e-service quality studies analyse the effect of perceived quality on satisfaction, repurchasing, revisiting intention, or loyalty, but none of them deal with word-of-mouth, although this would be a relevant and interesting research topic (Chang et al., 2009).

In this study we investigate only one aspect of satisfaction, word of mouth (Dolen, Dabholkar, \& Ruyter, 2007, Ltifi \& Gharbi, 2012), which may be divided into traditional WOM and electronic WOM. Traditional WOM is defined as a negative or positive informal communication about a business or its products and services (Tax, Chandrasrekaran, and Christiansen, 1993), and e-WOM refers to "any positive or negative statements made by potentional, actual or former customers about a product or a company... via Internet " (Henning - Thurau, Gwinner, Walsh, \& Gremler, 2004, 39. pp.). During our research we will concentrate only on the traditional word-of-mouth intention.

\section{Empirical research}

Our research included two main phases. In the first phase the direct effect of perceived eservice quality's dimensions on satisfaction and on traditional word-of-mouth were analysed using the PLS-SEM method. The second phase provides a segmentation of the sample based on those perceptions of quality dimensions which are relevant to the satisfaction and word-ofmouth intention. In this part we also describe the different consumer segments by using multivariate analysis of variance. The data were analysed using Smart PLS 2.0 and SPSS 20.

A research was designed to measure perceived electronic-service quality in Hungary using the E-S-Qual and E-RecS-Qual scale. This scale was chosen because it is a well-accepted scale in marketing because its roots come from traditional service marketing (Parasuraman, Zeithaml, \& Malhotra, 2005). Word-of-mouth intention was also measured using a multi-item scale from Zeithalm, Berry, and Parasuraman (1996), and satisfaction was measured with one item described in Parasuraman, Zeithaml and Malhotra (2005).

The data were collected about the users of one of the most popular Hungarian online bookshops. An online bookstore was chosen because most Hungarian e-shoppers buy books on the Internet (NRC, 2009). An online survey was used and in one week 277 responses arrived. Table 1. shows a description of the sample. The translation of the scale was a two-stage process: first the English scale was translated to Hungarian, and after that the Hungarian items were translated to English. With this checking process, the validity of the scale was guaranteed.

Table 1: Profiles of the sample (authors' own data)

\begin{tabular}{|c|c|c|c|c|c|}
\hline $\mathrm{N}=277$ people & Freq. & $\%$ & $\mathrm{~N}=277$ people & Freq. & $\%$ \\
\hline \multicolumn{3}{|l|}{$\operatorname{Sex}^{1}$} & \multicolumn{3}{|c|}{ For how long have you been using the web-store? } \\
\hline Male & 45 & $16 \%$ & For less than 3 months & 17 & $6 \%$ \\
\hline \multicolumn{3}{|l|}{ Age } & for $6-10$ months & 41 & $15 \%$ \\
\hline$<20$ & 21 & $8 \%$ & For more than 1 year & 202 & $73 \%$ \\
\hline $20-29$ & 78 & $28 \%$ & \multicolumn{3}{|c|}{ How often do you visit this web-store? } \\
\hline $40-49$ & 41 & $15 \%$ & 5-8 times per month & 103 & $37 \%$ \\
\hline$>49$ & 42 & $15 \%$ & 9-12 times per month & 52 & $19 \%$ \\
\hline \multicolumn{3}{|c|}{ Net monthly income } & More than 12 times per month & 66 & $24 \%$ \\
\hline
\end{tabular}

\footnotetext{
${ }^{1}$ According to a survey by Gemius, $60 \%$ of website users are women.
} 


\begin{tabular}{|l|l|l|l|l|l|}
\hline$>50.000$ HUF* & 65 & $26 \%$ & When was your last purchase? & \multicolumn{1}{l|}{} \\
\hline $50.000-99.999$ HUF & 87 & $35 \%$ & Less than a week age & 40 & $14 \%$ \\
\hline $100.000-149.999$ HUF & 48 & $19 \%$ & $1-2$ weeks ago & 41 & $15 \%$ \\
\hline $150.000-199.999$ HUF & 35 & $14 \%$ & $3-4$ weeks ago & 22 & $8 \%$ \\
\hline $200.000-499.999$ HUF & 16 & $6 \%$ & $5-8$ weeks ago & 43 & $16 \%$ \\
\hline$>499.999$ HUF & 1 & $0,4 \%$ & more than 8 weeks ago & 131 & $47 \%$ \\
\hline n.d. & 25,00 & $9 \%$ & The last average purchase size & 5004 HUF* \\
\hline$* 230$ HUF $~ 1$ USD Jan 2014) & \multicolumn{7}{|l}{} \\
\hline
\end{tabular}

The PLS technique was used to estimate the relationships between the latent variables. The use of this method is recommended for relatively low sample numbers (Henseler, 2010), or when the construct scores are required for the analysis (Mandják, Henseler, Simon, \& Szalkai, 2012).

Before analysing the expected relationships, the reliability and validity of the scales - such as the internal consistency reliability, convergence validity, and discriminant validity - should be tested (table 2-3.). Our results show that the scales used have the expected reliability and validity and were suitable for use in our analyses.

Table 2: The reliability and validity of the multi-item scales employed (authors' own data)

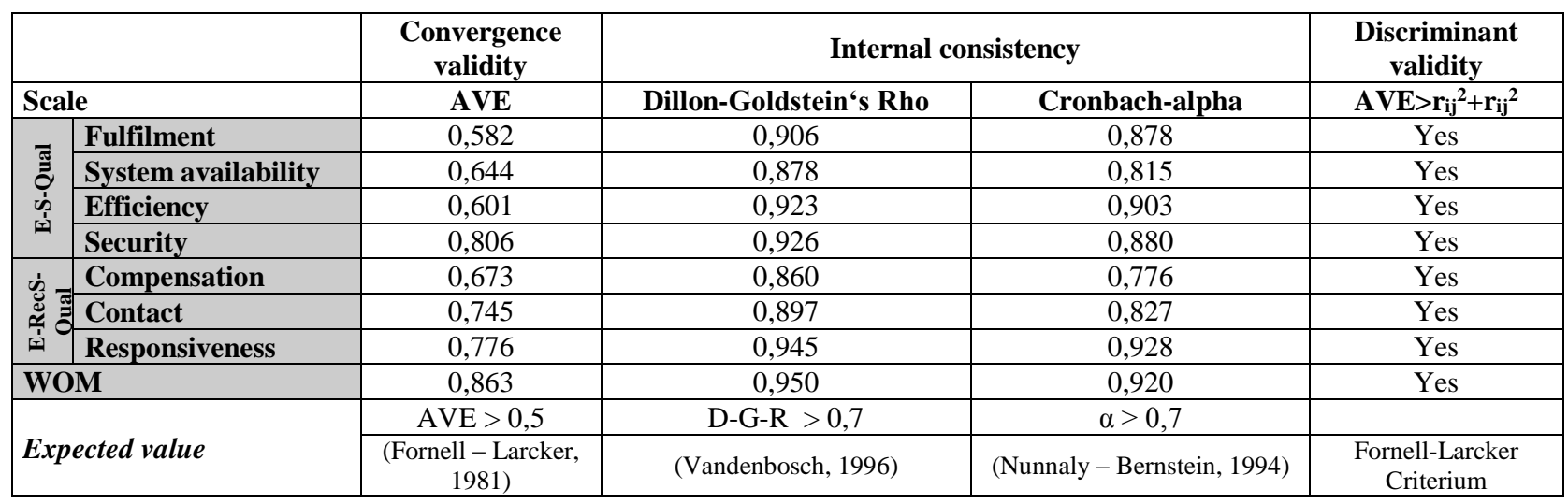

\begin{tabular}{|c|c|c|c|c|c|c|c|c|c|}
\hline \multicolumn{10}{|c|}{ Fornell-Larcker Criterium } \\
\hline & Sec & Sys.Av & Eff & Cont & Comp & SAT & Ful & Resp & WOM \\
\hline Sec & $\mathbf{0 , 8 0 6}$ & & & & & & & & \\
\hline Sys.Av & 0,187 & 0,644 & & & & & & & \\
\hline Eff & 0,246 & 0,462 & 0,601 & & & & & & \\
\hline Cont & 0,386 & 0,198 & 0,340 & $\mathbf{0 , 7 4 5}$ & & & & & \\
\hline Comp & 0,236 & 0,086 & 0,169 & 0,333 & $\mathbf{0 , 6 7 3}$ & & & & \\
\hline SAT & 0,192 & 0,327 & 0,503 & 0,248 & 0,131 & 1,000 & & & \\
\hline Ful & 0,360 & 0,178 & 0,340 & 0,334 & 0,203 & 0,207 & $\mathbf{0 , 5 8 2}$ & & \\
\hline Resp & 0,380 & 0,167 & 0,322 & 0,654 & 0,515 & 0,286 & 0,274 & 0,776 & \\
\hline WOM & 0,183 & 0,265 & 0,453 & 0,230 & 0,147 & 0,419 & 0,262 & 0,298 & $\mathbf{0 , 8 6 3}$ \\
\hline
\end{tabular}

The explained variances of the endogenous variables are substantial $\left(\mathrm{R}^{2} \mathrm{SAT}=0,612\right.$, $\mathrm{R}^{2}$ wom $\left.=0,558\right)$. The path coefficient of the variables shows that the efficiency, system availability and responsiveness have a relevant positive effect on satisfaction, $\left(\beta_{57}=0,550\right.$, $\left.\beta_{58}=0,144, \beta_{58}=0,264\right)$. The effect of efficiency, fulfilment, responsiveness, contact and satisfaction on word-of-mouth intention is also higher than $+/-1$ path coefficient $(\beta 58=0,248$, $\beta 58=0,165, \beta 58=0,247, \beta 58=-0,128, \beta 58=0,338$ ) (Table 3.).

In order to observe the significance of the assumed relationships, the following hypotheses should be analysed by using the bootstrapping method (sample size 5000) (Table 3.): H0: $\beta=0$, the path coefficient does not significantly differ from 0 . 
$\mathrm{H} 1: \beta \neq 0$

Table 3: Path coefficients and results of analysis of hypotheses (authors' own data)

\begin{tabular}{|c|c|c|c|}
\hline & path coeff & t-stat & sig. level $5 \%$ \\
\hline & & & $t_{\mathrm{emp}}=1,67$ \\
\hline efficiency $\rightarrow$ SAT & $\mathbf{0 , 5 5 0}$ & 5,678 & $\checkmark \quad($ do not reject $)$ \\
\hline system availability $\rightarrow$ SAT & 0,144 & 1,454 & 凶 (do reject) \\
\hline fulfilment $\rightarrow$ SAT & $-0,029$ & 0,348 & $\triangle \quad$ (do reject) \\
\hline privacy $\rightarrow$ SAT & 0,016 & 0,223 & 区 (do reject) \\
\hline responsiveness $\rightarrow$ SAT & 0,264 & 2,501 & $\checkmark \quad($ do not reject $)$ \\
\hline compensation $\rightarrow$ SAT & $-0,034$ & 0,697 & 区 (do reject) \\
\hline contact $\rightarrow$ SAT & $-0,037$ & 0,425 & (do reject) \\
\hline efficiency $\rightarrow$ WOM & 0,248 & 1,837 & $\checkmark \quad($ do not reject $)$ \\
\hline system availability $\rightarrow$ WOM & 0,054 & 0,600 & 区 (do reject) \\
\hline fulfilment $\rightarrow$ WOM & 0,165 & 2,470 & $\checkmark \quad($ do not reject $)$ \\
\hline privacy $\rightarrow$ WOM & $-0,029$ & 0,389 & 凶 (do reject) \\
\hline responsiveness $\rightarrow$ WOM & $\mathbf{0 , 2 4 7}$ & 2,324 & $\checkmark($ do not reject $)$ \\
\hline compensation $\rightarrow$ WOM & $-0,033$ & 0,651 & 区 (do reject) \\
\hline contact $\rightarrow$ WOM & $-0,128$ & 1,383 & 区 (do reject) \\
\hline sat $\rightarrow$ WOM & $\mathbf{0 , 3 3 8}$ & 3,305 & $\checkmark($ do not reject $)$ \\
\hline
\end{tabular}

Our results show that the variance of online consumers satisfaction is explained $61.2 \%$ by the positive effects of efficiency (path of 0.55), and responsiveness (path of 0.264). The variance of word-of-mouth intention is explained $55.8 \%$ by the positive effects of efficiency (weight of 0.248 ), fulfilment (path of 0.165 ) responsiveness (path of 0.247 ), and satisfaction (weight of 0.338). To analyse our hypothesis we used the significant level of $5 \%$.

In order to identify the different types of consumers' perceptions, hierarchical cluster analyses with Ward method was used, based on the latent variable scores. In the analyses only exogenous latent variables which have a significant effect on satisfaction and word-of-mouth intention (efficiency, fulfilment and responsiveness) were used. With this segmentation our aims were (1) to find out which segments were relevant in terms of satisfaction and WOM intention, and (2) to analyse the relationship between the relevant segments.

In order to analyse the segments we decided to use a 4 cluster solution. To analyse the differences in the clusters, variance analyses was used.

\section{Evaluation and results}

Based on the significant antecedences of satisfaction and word-of-mouth intention, four segments were established by using the hierarchical cluster analyses with Ward method in SPSS. Table 4 contains the characteristics of the four clusters. The 0 value shows the average quality perception with the analysed construct, values above 0 indicate a higher perceived quality and values below 0 mean a weaker perception of quality. In our solution one cluster has only 6 members; nevertheless we decided to use this classification because this segment still exists independently in the three cluster solution.

Table 4: Characteristics of the segments (authors' own data)

\begin{tabular}{|c|c|c|c|c|}
\hline & Clusters (Ward method) & $\mathbf{N}$ & Mean & Std. Deviation \\
\hline \multicolumn{5}{|c|}{ Variables that were used in cluster analysis } \\
\hline EFF & Technology underrated segment & 45 & $-1,445$ & 0,757 \\
\hline
\end{tabular}




\begin{tabular}{|c|l|c|c|c|}
\multirow{5}{*}{} & Happy segment & 172 & 0,483 & 0,472 \\
\cline { 2 - 5 } & Website's soft skills underrated & 54 & $-0,071$ & 0,563 \\
\cline { 2 - 5 } & Unhappy segment & 6 & $-2,357$ & 2,416 \\
\cline { 2 - 5 } & Total & 277 & 0,000 & 1,002 \\
\hline \multirow{5}{*}{ FULF } & Technology underrated segment & 45 & $-0,952$ & 0,677 \\
\cline { 2 - 5 } & Happy segment & 172 & 0,413 & 0,468 \\
\cline { 2 - 5 } & Website's soft skills underrated & 54 & $-0,010$ & 0,573 \\
\cline { 2 - 5 } & Unhappy segment & 6 & $-4,602$ & 0,987 \\
\cline { 2 - 5 } & Total & 277 & 0,000 & 1,002 \\
\hline \multirow{5}{*}{ RESP } & Technology underrated segment & 45 & $-0,911$ & 0,950 \\
\cline { 2 - 5 } & Happy segment & 172 & 0,633 & 0,327 \\
\cline { 2 - 5 } & Website's soft skills underrated & 54 & $-1,109$ & 0,615 \\
\cline { 2 - 5 } & Unhappy segment & 6 & $-1,338$ & 1,763 \\
\cline { 2 - 5 } & Total & 277 & 0,000 & 1,002 \\
\hline Variables & that were not used in cluster analysis & & & \\
\hline \multirow{5}{*}{ WOM } & Technology underrated segment & 46 & $-1,280$ & 1,472 \\
\cline { 2 - 5 } & Happy segment & 109 & 0,433 & 0,434 \\
\cline { 2 - 5 } & Website's soft skills underrated & 61 & $-0,002$ & 0,813 \\
\cline { 2 - 5 } & Unhappy segment & 61 & 0,194 & 0,599 \\
\cline { 2 - 5 } & Total & 277 & 0,000 & 1,002 \\
\hline \multirow{5}{*}{ SAT } & Technology underrated segment & 46 & $-1,263$ & 1,484 \\
\cline { 2 - 5 } & Happy segment & 109 & 0,528 & 0,366 \\
\cline { 2 - 5 } & Website's soft skills underrated & 61 & $-0,007$ & 0,638 \\
\cline { 2 - 5 } & Unhappy segment & 61 & 0,016 & 0,765 \\
\cline { 2 - 5 } & Total & 277 & 0,000 & 1,002 \\
\hline
\end{tabular}

Based on the used latent variable scores, three from the four segments evaluated as less than average the relevant dimensions of the electronic service quality. The most dissatisfied segment included only six members and they were labelled the 'Unhappy'-s. The second smallest segment has 45 members. Their average quality perception is also lower then 0 ( 0 being the average perception) within all dimensions, but the evaluations of the relevant technology-based dimension (efficiency) and delivery differ significantly from the other segments: significantly better than the rating of the 'Unhappy'-s (sig=0,000), but significantly lower than the average of the other segments. This group could be called the 'Technology underrated' segment. The third segment's evaluation of the technology-based dimension and the fulfilment is around average, but the rating of the human-based dimension (responsiveness) does not differ significantly from the 'Unhappy'-s and the 'Technology underrated' segments. This cluster also perceived this dimension to be less than average. This segment has 54 members, and because of their characteristics they could be called the 'Website's soft skills underrated' segment. The fourth segment's average scores are always above 0 , and their ratings differ significantly from all of the other segments' ratings. This 'Happy' segment has 172 members. However, while the latent scores of the 'Happy' segment significantly differs from the others, detailed item analysis shows that the perception of two items of fulfilment2 does not significantly differ from the Website's soft skills underrated' segment.

Based on the analysis of the overall levels of satisfaction, the 'unhappy' and the 'technology underrated' segment do not differ significantly: they have a similar under the average satisfaction level. The soft skills underrated segment overall satisfaction is also negative, but it is closer to zero. Only the 'happy' segment has a positive overall satisfaction level and wordof-mouth intention score. However, the average latent scores of word-of-mouth intention differ significantly between all the segments.

\footnotetext{
${ }^{2}$ FUL1: It delivers orders when promised., FUL6: It is truthful about its offerings.
} 


\section{Research contribution}

In our paper the most relevant aspects of electronic service quality were summarized based on the literature, and we examined further which dimensions have a relevant effect on satisfaction and traditional word-of-mouth intention in a Hungarian online bookstore.

As our conclusion we may say that some of the analysed electronic service quality scales do not have content validity because they do not perfectly fit to the definition of e-service quality. Based on this definition, electronic service quality is an umbrella construct which includes not only the perceptions of the web-store characteristics but also post interactions such as delivery and consumer service. That means that electronic service quality has two relevant aspects: (1) a technology-based component - the characteristics of the web-store, the usability which could be developed using different IT tolls -, and (2) a human-based component. On the one hand this includes the reliability of the information on the site and the general reliability of the web-shop - these dimensions belong to the online environment -, and on the other hand consumer service, complaints and returns, which belong to the offline environment. This indicates that electronic service quality is complex construct, which is further complicated by the fact that most web-shops do not have their own delivery service so they outsource this service to other delivery companies. It is thus important to distinguish between internal and external dimensions.

Most of the electronic service quality scale also includes the dimension of the privacy and security, which is mostly a technology-based component - for example the security of payment, personal information -, but it could also have a human-based side - for example, how do the web-store managers handle personal information.

Considering the characteristics of the exiting electronic service quality scales, we decided to use in our research E-S-Qaul, and a secondary scale, E-RecS-Qual, to measure the e-service quality perceptions of consumers and its relationship to satisfaction and word-of-mouth intention. This scales measures the e-sq in seven dimensions such as: efficiency, system availability, privacy - these are the technology-based dimensions - and fulfilment, responsiveness, compensation and contact - which are the human-based characteristics.

According to our research into the online bookstore only the dimension of efficiency and responsiveness have a significant positive effect on satisfaction, and beside these dimensions the perception of the quality of fulfilment's also significantly influences word-of-mouth intention.

Using the latent variable scores of these relevant e-SQ dimensions a segmentation method was developed in which four segments were identified. The largest segment is the happy segment with 172 members. They evaluated all quality dimensions as being above average, and they had the highest levels of satisfaction and word-of-mouth intention. The second biggest segment is the web-site's soft skills underrated group with 54 members. Their perception of the technology-based dimensions and delivery is around average but they rated the human-based interactions of the web-store and the privacy lower. The technology underrated segments has 45 members who evaluated all dimensions lower than average, but IT based components - such as efficiency and system availability - and privacy got the lowest evaluation. The unhappy segment - with only 6 members - rated the web-store's quality the weakest. These three segments' satisfaction and word-of-mouth intention is below average, but the web-site's soft skills underrated group is the closest to the average. These results indicate that the evaluation of the technology-based components has the greatest effect on satisfaction and word-of-mouth intention. 


\section{Managerial contributions}

In our paper we have presented information about which perceived dimension could influence the satisfaction and the word-of-mouth intention in e-commerce. In an online environment competition is really intensive and the switching costs are relatively small. This is why it is especially important to analyse the antecedents of loyalty; based on the literature satisfaction is one of the most important of them. Most of the studies treat word-of-mouth as a component of loyalty. Loyalty indicates a long-term relationship, but we have done only one piece of ad-hoc research which focused only on the most recent purchase; namely, we measured only word-of-mouth intention.

Our research shows that in e-commerce satisfaction and word-of-mouth intention are influenced by some technology-based as well some human- based components of e-service quality, but technology-based components are more important. In word-of-mouth intention fulfilment also plays an important part, although this is usually an outsourced function of the company, such as in the case of the bookstore company analysed. These results also indicate that with web-shops managers should focus not only on online features but also on offline human-based interactions and on the quality of their partners (for example, delivery services).

Beside these results we also presented a potential method for segmentation which uses the scores of complex, multi-item constructs. With this segmentation managers can establish segment specific strategies. In the case of the analysed online bookstore, if the shop wanted to concentrate to the web-site's soft skills underrated group, the first step should be to improve the responsiveness of the company. But if the technology underrated segments is more important to the company, then the technology based components of the website and after that the delivery method should firstly be improved. First of all, efficiency (usability, design and navigation) should be improved.

Appendix 1: Outer Loadings

\begin{tabular}{|c|c|c|c|c|c|c|c|c|c|}
\hline & EFF & FULF & SYSA & SEC & COMP & CONT & RESP & SAT & WOM \\
\hline EFF_1 & 0,786 & & & & & & & & \\
\hline EFF_2 & 0,903 & & & & & & & & \\
\hline EFF_3 & 0,67 & & & & & & & & \\
\hline EFF_4 & 0,81 & & & & & & & & \\
\hline EFF_5 & 0,652 & & & & & & & & \\
\hline EFF_6 & 0,844 & & & & & & & & \\
\hline EFF_7 & 0,674 & & & & & & & & \\
\hline EFF_8 & 0,82 & & & & & & & & \\
\hline FULF_1 & & 0,786 & & & & & & & \\
\hline FULF_2 & & 0,829 & & & & & & & \\
\hline FULF_3 & & 0,807 & & & & & & & \\
\hline FULF_4 & & 0,758 & & & & & & & \\
\hline FULF_5 & & 0,743 & & & & & & & \\
\hline FULF_6 & & 0,557 & & & & & & & \\
\hline FULF_7 & & 0,821 & & & & & & & \\
\hline SYSA_1 & & & 0,806 & & & & & & \\
\hline SYSA_2 & & & 0,835 & & & & & & \\
\hline SYSA_3 & & & 0,866 & & & & & & \\
\hline SYSA_4 & & & 0,687 & & & & & & \\
\hline SEC_1 & & & & 0,887 & & & & & \\
\hline SEC_2 & & & & 0,912 & & & & & \\
\hline SEC_3 & & & & 0,893 & & & & & \\
\hline COMP_1 & & & & & 0,874 & & & & \\
\hline COMP_2 & & & & & 0,833 & & & & \\
\hline COMP_3 & & & & & 0,752 & & & & \\
\hline CONT_1 & & & & & & 0,769 & & & \\
\hline
\end{tabular}




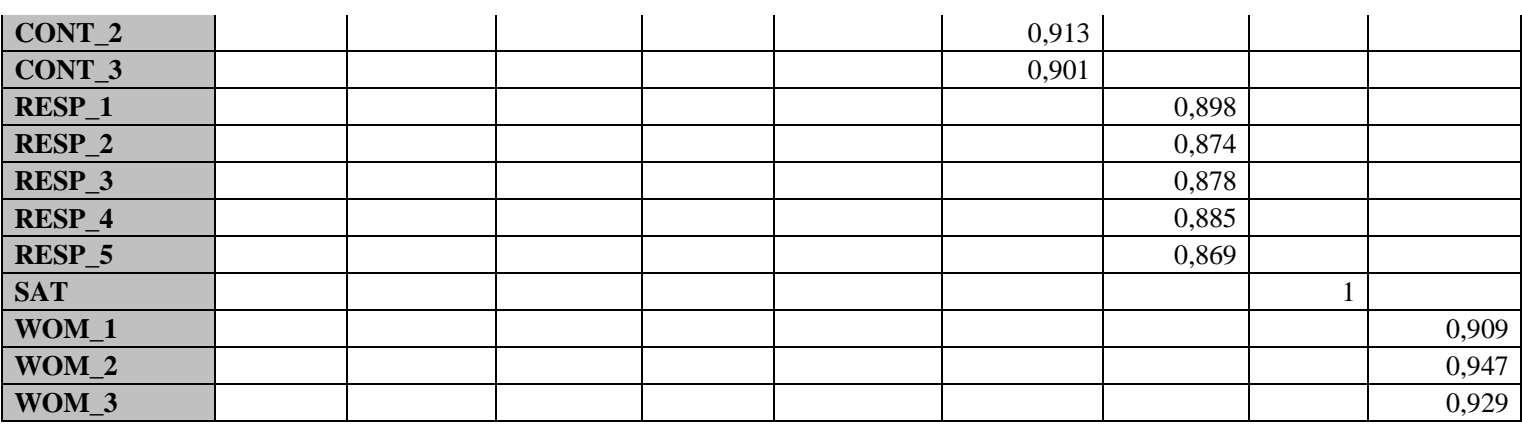

\section{References}

Anderson, R. E., \& Srinivasan, S. S. (2003). E-Satisfaction and E-Loyalty: A Contingency Framework. Psychology \& Marketing, 20(2), 123-138.

Backhaus, K., Erichson, B., Plinke, W., \& Weiber, R. (2006). Multivariate Analysemethoden; Berlin: Springer, 338-412.

Barnes, S.I., \& Vidgen, R. (2001). An Evaluation of Cyber-Bookshops: The WebQual Method. International Journal of Electronic Commerce 6, 11.

Bressolles, G., Durrieu, F., \& Giraud, M. (2007). The impact of electronic service quality's dimensions on customer satisfaction and buying impulse; Journal of Customer Behaviour, $6(1), 37-56$.

Carlson, J., \& O’Cass, A. (2011). Developing a framework for understanding e-service quality, its antecedents, consequences, and mediators. Managing Service Quality 21, 264-286.

Chang, H. H., Wang, Y. H., \& Yang, W.Y. (2009). The impact of e-service quality,customer satisfaction and loyalty on e-marketing: moderating effect of perceived value; Total quality management \& business excellence, 2 (4), 423-443.

Cronin Jr., J.J., \& Taylor, S.A., 1992. Measuring Service Quality: A Reexamination and Extension. Journal of Marketing 56, 55-68.

E-kereskedelmi trendek 2011-ben (eNet); http://gkienet.hu/hu/hirek/e-kereskedelmi-trendek2011-ben/ (downloaded: 10 Dec, 2014.)

Enet (2012). E-kereskedelmi trendek 2011-ben [E-commerce trends in 2011[. http://gkienet.hu/hu/hirek/e-kereskedelmi-trendek-2011-ben/ (downloaded: 12nd Jan, 2015.)

Eurostat reports (2013), http://epp.eurostat.ec.europa.eu/portal/page/portal/statistics. (Downloaded: Dec 11, 2014).

Folkes, V.S. (1984). Consumer Reactions to Product Failure: An Attributional Approach. Journal of Consumer Research 10, 398-409.

Fornell, C., \& Larcker, D. F. (1981). Evaluating Structural Equation Models with Unobservable Variables and Measurement Error. Journal Of Marketing Research (JMR), 18(1), 39-50.

Francis, J. E. (2009). Category-specific RECIPEs for Internet retailing quality. Journal of Services Marketing, 23(7), 450-461.

Francis, J. E., \& White, L. (2002). Pirqual: a scale for measuring customer expectations and perceptions of quality in Internet retailing. (Vol. 13, p. 263). Presented at the AMA Winter Educators' Conference Proceedings.

Godwin, U.J., Bagchi, K.K., \& Kirs, P.J. (2010). An assessment of customers' e-service quality perception, satisfaction and intention. International Journal of Information Management 30, 481-492.

Hennig-Thurau, Th., Gwinner, K.P., Walsh, G., \& Gremler, D.D. (2004). Electronic word-ofmouth via consumer-opinion platforms: what motivates consumers to articulate themselves 
on the Internet? JOURNAL OF INTERACTIVE MARKETING, 18 (1), 38 - 52.

Henseler (2010). On the convergence of the partial least squares path modeling algorithm. Comput Stat, 25, 107-120.

Hill (1986). Satisfaction and consumer services. Advances in Consumer Research, 13, 311-315. Hofmeister-Tóth, Á., Simon, J., \& Sajtos, L. (2003). Fogyasztói elégedettségmérés [Consumer satisfaction measurement]. Budapest: Alinea Kiadó

Kemén, I., Ugray, Zs, \& Simon, J. (2013). Online-consumer satisfaction and word of mouth in case of services buyers and products buyers. EMAC Regional Conference, Sept 2013. St. Petersburg.

Kenesei, Zs., Kolos, K., 2007. Szolgáltatásmarketing és -menedzsment. Budapest: Alinea Kiadó.

Loiacono, E.T., Watson, R.T., \& Goodhue, D.L. (2007). WebQual: An Instrument for Consumer Evaluation of Web Sites. International Journal of Electronic Commerce 11, 51-87.

Ltifi, M., \& Gharbi, J.-E. (2012). E-satisfaction and e-loyalty of consumers shopping online. Journal of Internet Banking \& Commerce, 17(1), 1-20.

Mandják, T., Henseler, J., Simon, J., \& Szalkai, Zs. (2012). Typology of business relationships using buyers' and suppliers' perceptions. The IMP Journal, 6 (2), 109-134.

Meuter, M. L., Ostrom, A. L., Roundtree, R. I., \& Bitner, M. J. (2000). Self-Service Technologies: Understanding Customer Satisfaction with Technology-Based Service Encounters. Journal of Marketing, 64(3), 50-64.

Meuter, M. L., Ostrom, A. L., Roundtree, R. I.,\& Bitner, M. J. (2000). Self-service technologies: understanding customer satisfaction with technology-based service encounters; Journal of marketing, 64 July, 50-64.

NRC Piackutató Kft. (2009): E-Commerce Trend Report 2009- lakossági kutatás; http://nrc.hu/termekek/ecommerce (downloaded: Sept 25, 2011)

Nunnally, J. C., \& Bernstein, I. H. (1994). Psychometric theory (3rd ed.). New York: McGrawHill.

Oliver, R.L., \& Rust, R.T. (1997). Customer Delight: Foundations, Findings, and Managerial Insight. Journal of Retailing 73, 311-336.

Parasuraman, A., Zeithaml, V. A., \& Malhotra, A. (2005). E-S-QUAL: A Multiple-Item Scale for Assessing Electronic Service Quality. Journal of Service Research, 7(3), 213-233.

Szymanski, D.M, \& Henard, D.H. (2001). Customer Satisfaction:A Meta-Analysis of the Empirical Evidence. Journal of the Academy of Marketing Science 29, 16 - 35.

Tax, S. S., Chandrasrekaran, M. \& Christiansen, T. (1993). Word of mouth in customer decisionmaking: an agenda for research. Journal of Consumer Satisfaction, Dissatisfaction and Complaining Behavior, 6, 74-80.

van Dolen, W. M., Dabholkar, P. A., \& de Ruyter, K. (2007). Satisfaction with Online Commercial Group Chat: The Influence of Perceived Technology Attributes, Chat Group Characteristics, and Advisor Communication Style. Journal Of Retailing, 83(3), 339-358.

Wolfinbarger A, M., \& Gilly, M. C. (2003). Etailq: dimensionalizing, measuring and predicting etail quality; Journal of retailing, 79, 183-198.

Yoo, B., \& Donthu, N., (2001). Developing a scale to measure the preceived quality of an Internet shopping site: SITEQUAL. Quarterly Journal of Electronic Commerce, 1 - 19.

Zeithaml, V. A., Berry, L. L., \& Parasuraman, A. (1996). The Behavioral Consequences of Service Quality. Journal of Marketing, 60(2), 31-46 